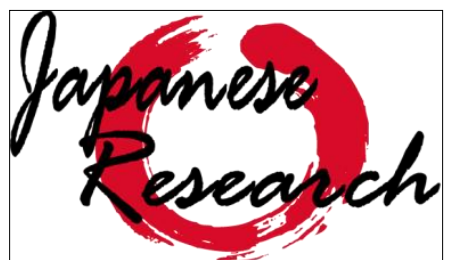

on Linguistics, Literature, and Culture
Japanese Research on Linguistics, Literature, and Culture Vol. 1 No. 1 Nov. 2018, Hal. 48-64, ISSN: 2655-4836

https://publikasi.dinus.ac.id/index.php/irllc/article/view/2100/1381

Published by Universitas Dian Nuswantoro,

Jl. Imam Bonjol 207, Semarang

\title{
Makna Mimpi, Kematian, dan Kecemasan pada Cerpen Shirakawa Yo Fune Karya Yoshimoto Banana
}

\author{
Fairuz Jamaan
}

Universitas Nasional

fai idrus@yahoo.com

Article History: Submitted date 2018-11-10; Accepted date 2018-11-28; Published date 2018-11-28

\begin{abstract}
This article aimed to describe a human confusion and inner turmoil that is often found in the lives of modern society in Japan, such as the infidelity, love, death, and anxiety that trigger inner conflict through the analysis of characters in the short story Shirakawa Yo Fune, by Yoshimoto Banana. This article uses Sigmund Freud's theory of literary psychoanalysis. The analysis shows the lives of characters are so individuayl and does not interact much with the surrounding community, so that the death of the only person closest triggers anxiety in the character. Anxiety occurs because the tensions are not well reduced. So each character identifies and displacemen to reduced the anxiety. It also motivates character to carry out defense mechanisms in the form of repression which then dreams, daydreaming and fixation. Furthermore analysis of dreams and daydream shows that these situation in case of condensation, displacemen and symbolization.
\end{abstract}

Keywords: fixation, condensation, dream, displacemen, symbolization 


\begin{abstract}
Abstrak
Penelitian ini membahas kekalutan dan kekacauan batin manusia yang banyak dijumpai pada kehidupan masyarakat modern di Jepang, seperti perselingkuhan, percintaan, kematian, dan kecemasan yang memicu konflik batin melalui analisis tokoh tokoh pada cerita pendek Shirakawa Yo Fune, karya Yoshimoto Banana. Penelitian menggunakan teori psikoanalisis sastra Sigmund Freud. Analisis yang dilakukan memperlihatkan kehidupan para tokoh yang sangat individual dan tidak banyak berinteraksi dengan masyarakat sekitar sehingga kematian satu-satunya orang terdekat memicu kecemasan pada diri tokoh. Kecemasan terjadi karena ketegangan-ketegangan yang tidak tereduksi dengan baik. Untuk mengatasi ketegangan, tiap-tiap tokoh melakukan identifikasi dan pemindahan Kecemasan juga memotivasi tokoh untuk melakukan mekanisme pertahanan berupa represi yang kemudiam memicu munculnya mimpi, lamunan serta, fiksasi. Selanjutnya analisis terhadap mimpi dan lamunan menunjukkan bahwa mimpi serta lamunan tersebut telah mengalami kondensasi, pemindahan, dan simbolisasi
\end{abstract}

Kata Kunci: fiksasi, kondensasi, mimpi, pemindahan, simbolisasi

\title{
1. Pendahuluan
}

Karya sastra merupakan produk dari suatu keadaan kejiwaan dan pemikiran pengarang yang berada dalam situasi setengah sadar, setelah mendapat bentuk yang jelas dituangkan ke dalam bentuk tertentu secara sadar dalam bentuk penciptaan karya sastra. Karya sastra yang bermutu adalah suatu karya yang mampu menggambarkan kekalutan dan kekacauan batin manusia karena hakikat kehidupan manusia adalah perjuangan menghadapi kekalutan batinnya sendiri. Karya sastra yang baik mampu menyajikan simbol-simbol, wawasan, perlambangan yang bersifat universal yang mempunyai kaitan dengan mitologi, kepercayaan, tradisi, moral, budaya dan lain-lain. Jadi sastra dapat juga dijadikan cermin untuk melihat wajah masyarakat dan kebudayaannya

Yoshimoto Banana adalah salah satu pengarang Jepang kontemporer yang banyak menghasilkan karya yang menggambarkan kekalutan dan kekacauan batin manusia. Yoshimoto yang lahir 24 Juli 1964 adalah putri dari Yoshimoto Takaaki seorang kritikus, intelektual, dan pemimpin dalam gerakan mahasiswa radikal akhir tahun 1960 di Jepang. Yoshimoto Banana tumbuh dalam keluarga liberal. Karya-karya Yoshimoto banyak mendapat pengaruh dari penulis dari Barat seperti, Stephen King, Truman Capote, dan Isaac Bashevis Singer. 
Yoshimoto adalah salah satu penulis Jepang yang popular di seluruh dunia. Karyakaryanya berupa 12 novel dan 7 koleksi esainya, sudah diterjemahkan ke dalam bahasa Inggris dan terjual lebih dari 6 juta kopi di seluruh dunia. Beberapa novelnya yang telah diterjemahkan ke dalam bahasa Inggris adalah Moonlight Shadow, Kitchen, Asleep, Goodbye Tsugumi, N.P, Amrita, dan lain lain.

Sebahagian besar dari novel-novel yang ditulis Yoshimoto menceritakan kejiwaan manusia dalam masyarakat modern, seperti percintaan, perselingkuhan, persahabatan, keluarga, kesedihan, kematian, mimpi, dan konflik-konflik batin yang banyak dijumpai pada masyarakat modern dewasa ini. Walaupun daya tarik Yoshimoto tidak terlalu jelas bagi para kritikus berbahasa Inggris karena mereka membaca karya dalam bentuk terjemahan dan tidak terbiasa dengan budaya Jepang, tetapi mereka menyebut karakter-karakter tokoh Yoshimoto luar biasa dan unik. Pada penelitian ini penulis membahas cerpen Shirakawa Yo Fune yang sudah diterjemahkan ke dalam bahasa Inggris menjadi Asleep.

Cerita pendek Shirakawa Yo Fune adalah salah satu dari tiga cerita pendek yang teerdapat di novel Shirakawa Yo Fune. Dua cerita pendek yang lain adalah Yoru to Yoru no Futatabi dan Arutaiken. Cerita-cerita pendek tersebut menceritakan percintaan, perselingkuhan, persahabatan yang dikaitkan dengan kematian, mimpi dan kecemasan. Alur cerita tampaknya didominasi oleh tidur, mimpi, dan kecemasan yang semuanya diceritakan dari sudut pandang seorang wanita muda. Mimpi menurut Aristoteles adalah kehidupan pikiran selama tidur, kehidupan yang menyerupai saat kita bangun hanya saja lebih sempit (in Freud, 2002, p.84). Mimpi adalah penghubung antara kondisi bangun dan tidur. Selanjutnya Freud berpendapat mimpi merupakan perwujudan hasrat yang tidak terpenuhi dalam kehidupan nyata, sehingga mimpi dapat dianggap sebagai pemindahan hasrat-hasrat yang tidak tersalurkan dan dapat berujung pada kecemasan dan akan mempengaruhi perkembangan kejiwaan manusia

Permasalahan yang diangkat dalam penelitian ini adalah membahas makna mimpi serta kaitannya dengan kematian dan kecemasan pada tokoh-tokoh cerita pendek Shirakawa Yo Fune. 


\subsection{Kajian Teoretis}

Menurut Endraswara, psikologi sastra adalah suatu disiplin ilmu yang memandang karya sastra sebagai suatu karya yang memuat peristiwa-peristiwa kehidupan manusia yang diperankan oleh tokoh-tokoh imajiner yang ada di dalamnya atau mungkin juga diperankan oleh tokoh-tokoh faktual. Tujuan dari psikologi sastra adalah memahami unsur-unsur kejiwaan dalam suatu karya melalui pemahaman para tokoh (Endraswara, 2008). Terdapat banyak teori yang dapat digunakan dalam psikologi sastra diantaranya adalah psikoanalisis Sigmund Freud.

Freud mengarahkan eksplorasinya ke dalam dunia tidak sadar dan berkeyakinan bahwa manusia termotivasi oleh dorongan-dorongan utama yang belum atau tidak mereka sadari. Freud membagi kehidupan mental menjadi tiga tingkat, yaitu alam tidak sadar, alam sadar, dan alam bawah sadar. la menggambarkan alam sadar dengan gunung es, yakni bagian yang lebih kecil yang muncul di permukaan air, sedangkan alam bawah sadar adalah bagian gunung es yang berada di bawah permukaan air yang jauh lebih besar. Freud menyatakan bahwa pikiran manusia lebih dipengaruhi oleh alam bawah sadar ketimbang alam sadar walaupun dalam kehidupan sehari-hari kelihatannya hanya alam sadar yang muncul. Namun sebenarnya alam bawah sadar selalu aktif dan selalu siap muncul (Hall, Calvin S \& G Lindzey, 2005).

Alam Tidak Sadar menjadi tempat bagi segala dorongan, desakan maupun insting yang tak kita sadari tetapi ternyata mendorong perkataan, perasaan, dan tindakan kita. Freud menyatakan alam tidak sadar merupakan penjelasan dari makna yang ada di balik mimpi, kesalahan ucap, dan berbagai jenis lupa, yang dikenal sebagai represi. Mimpi adalah sumber yang kaya akan materi dari alam tidak sadar (Feist \& J. Feist., 2010). Kenangan yang tidak diinginkan dan memicu kecemasan direpresi masuk ke alam tak sadar. Tetapi terkadang kenangan tersebut bisa masuk ke alam sadar secara terselubung atau dengan wujud yang berbeda. Alam tidak sadar selalu aktif. Dorongan dorongan di alam tidak sadar terus menerus berupaya agar disadari, dan kebanyakan berhasil masuk ke alam sadar walaupun bukan dalam bentuk asli, tetapi terselubung agar tidak bisa dikenali, kadang kadang muncul dalam bentuk yang berlebiihan dan penuh kepura-puraan. Hal tersebut dalam mekanisme pertahanan dikenal dengan pembentukan reaksi 
Alam Bawah Sadar, terdiri dari dua sumber, yang pertama adalah persepsi sadar. Persepsi orang secara sadar dapat segera masuk ke alam bawah sadar ketika fokus perhatian beralih ke hal lain. Pikiran yang dapat keluar masuk antara alam sadar dan alam bawah sadar adalah pikiran yang bebas dari kecemasan. Sumber kedua dari gambaran-gambaran bawah sadar adalah alam tidak sadar. Menurut Freud pikiran dapat menyelinap masuk ke alam bawah sadar dalam bentuk yang tersembunyi (Feist \& J. Feist., 2010). Beberapa gambaran tersebut tidak kita sadari karena begitu kita menyadari kita akan merasa cemas dan berusaha mendorongnya kembali ke alam tidak sadar. Sejumlah gambaran lain dapat lolos dari alam tidak sadar masuk ke alam sadar karena bersembunyi dalam bentuk mimpi, salah ucap ataupun dalam bentuk pertahanan diri yang kuat.

Alam Sadar, ada dua pintu yang dapat dilalui oleh pikiran agar bisa masuk ke alam sadar. Pertama melalui sistem kesadaran perseptual yaitu hal-hal yang kita rasakan melalui indera dan tidak mengancam, masuk ke alam sadar. Kedua pikiran pikiran yang datang dari alam bawah sadar, maupun gambaran-gambaran yang membuat cemas yang sudah berubah wujud dan terselubung dalam bentuk perilaku-perilaku yang defensif ataupun dalam bentuk mimpi.

\subsubsection{Struktur Kepribadian}

Struktur Kepribadian tersusun dari 3 sistem pokok, yakni id, ego, dan superego. Ketiga sistem ini sudah tentu tidak nyata karena hanya merupakan hipotesis, namun ketiganya saling berinteraksi sehingga ego bisa masuk menembus berbagai tingkat yaitu alam sadar, alam bawah sadar,dan alam tidak sadar.Sementara super ego berada pada alam bawah sadar dan alam tidak sadar, sedangkan id sepenuhnya berada pada alam bawah sadar.

Id yang merupakan inti dari kepribadian yang sepenuhnya tak disadari. Id merupakan rahim tempat ego dan superego berkembang. Id berisikan segala sesuatu yang secara psikologis diwariskan dan telah ada sejak lahir, termasuk insting-insting. Id berhubungan erat dengan proses-proses jasmaniah dari mana id mendapatkan energinya. Id tidak bisa menanggulangi peningkatan energi yang dialaminya sebagai keadaan-keadaan tegangan yang tidak menyenangkan. Prinsip reduksi tegangan yang merupakan ciri kerja id disebut prinsip kenikmatan (pleasure principle). Untuk melaksanakan tugas menghindari rasa sakit dan mendapatkan kenikmatan, id memiliki dua proses. Kedua proses tersebut adalah tindakan 
refleks dan proses primer (Hall, Calvin S \& G Lindzey, 2005). Selanjutnya apabila proses primer tidak dapat memenuhi, maka id bergantung pada proses sekunder yang membuatnya dapat berhubungan dengan dunia luar. Fungsi proses sekunder ini dijalankan oleh ego.

Ego adalah satu-satunya wilayah pikiran yang memiliki kontak dengan realita. Ego dikatakan mengikuti prinsip kenyataan, dan beroperasi menurut proses sekunder. Tujuan prinsip kenyataan adalah mencegah terjadinya tegangan sampai ditemukan suatu objek yang cocok untuk pemuasan kebutuhan.(Hall, Calvin S \& G Lindzey, 2005)

Superego adalah perwujudan internal dari nilai-nilai dan cita-cita tradisional masyarakat sebagaimana diterangkan orangtua kepada anak, dan dilaksanakan dengan cara memberinya hadiah-hadiah atau hukuman-hukuman. Superego adalah wewenang moral dari kepribadian; ia mencerminkan yang ideal dan bukan yang real; dan memperjuangkan kesempurnaan dan bukan kenikmatan. Perhatiannya yang utama adalah memutuskan apakah sesuatu itu benar atau salah dengan demikian ia dapat bertindak sesuai dengan norma-norma moral yang diakui oleh wakil-wakil masyarakat (Hall, Calvin S \& G Lindzey, 2005).

\subsubsection{Dinamika Kepribadian}

Menurut Sigmund Freud seperti yang dikutip oleh Feist ((Feist \& J. Feist., 2010) mengusulkan sebuah dinamika atau prinsip motivasional untuk menerangkan kekuatankekuatan yang mendorong tindakan manusia. Manusia termotivasi untuk mencari kesenangan serta menurunkan ketegangan dan kecemasan. Motivasi itu diperoleh dari energi psikis dan fisik dari dorongan-dorongan dasar yang mereka miliki. Dorongan-dorongan tersebut dikenal dengan istilah insting. Insting didefinisikan sebagai perwujudan psikologis dari suatu sumber rangsangan somatik dalam yang dibawa sejak lahir. Perwujudan psikologisnya disebut hasrat sedangkan rangsangan jasmaniahnya dari mana hasrat itu muncul disebut kebutuhan. Hasrat itu berfungsi sebagai motif bagi tingkah laku. Karena itu insting-insting dilihat sebagai faktorfaktor pendorong kepribadian. Mereka tidak hanya mendorong tingkah laku tetapi juga menentukan arah yang akan ditempuh tingkah laku. Insting mempunyai sumber, tujuan, dan objek. Sumber telah didefinisikan sebagai kondisi jasmaniah atau kebutuhan. Tujuannya adalah menghilangkan perangsangan jasmaniah. Seluruh kegiatan yang menjembatani antara munculnya suatu hasrat dan pemenuhannya termasuk dalam objek. Insting dapat 
dikelompokkan dalam dua kelompok besar, yakni insting hidup dan insting mati. Insting hidup menjamin tujuan mempertahankan hidup individu dan perkembangan ras. Rasa lapar, haus, dan seks termasuk dalam kategori ini. Insting mati, atau disebut juga insting merusak (destruktif), melaksanakan tugasnya secara lebih sembunyi-sembunyi. Salah satu derifatif penting insting mati adalah dorongan agresi (Hall, Calvin S \& G Lindzey, 2005).

Kecemasan (Anxiety) adalah reaksi umum individu terhadap ancaman-ancaman rasa sakit dan perusakan dari luar yang tak siap ditanggulanginya. Menghadapi ancaman biasanya orang merasa takut. Kewalahan menghadapi stimulasi berlebihan yang tidak berhasil dikendalikan oleh ego, maka ego menjadi diliputi kecemasan. Kecemasan adalah suatu keadaan tegangan yang biasanya ditimbulkan oleh sebab-sebab dari luar. Apabila timbul kecemasan maka ia akan memotivasi seseorang untuk melakukan sesuatu, individu tersebut dapat lari dari daerah yang mengancam dan membahayakan atau menuruti suara hati. Fungsi kecemasan adalah bertindak sebagai tanda bahaya terhadap ego, bahwa kalau tidak dilakukan tindakantindakan tepat, maka bahaya itu akan meningkat sampai ego dikalahkan. Feist mengutip Freud ((Feist \& J. Feist., 2010) membagi kecemasan menjadi tiga, yaitu (1) kecemasan realistis adalah rasa takut akan bahaya nyata yang datang dari dunia luar. Kecemasan realitas merupakan tipe kecemasan pokok yang menjadi tempat asal dari dua kecemasan lainnya. (2) kecemasan neurosis adalah rasa takut akibat bahaya yang tidak diketahui. Perasaan ini berada pada ego, tetapi muncul dari dorongan-dorongan id. Kecemasan neurotik adalah ketakutan terhadap hukuman yang mungkin terjadi jika suatu insting dipuaskan. (3) kecemasan moral adalah rasa takut terhadap hati nurani. Orang-orang yang superegonya berkembang dengan baik cenderung merasa bersalah jika mereka melakukan atau bahkan berpikir untuk melakukan sesuatu yang bertentangan dengan norma moral dengan mana mereka dibesarkan. Mereka disebut mendengarkan bisikan suara hati.(Hall, Calvin S \& G Lindzey, 2005).

\subsubsection{Perkembangan Kepribadian}

Perkembangan kepribadian terjadi akibat meningkatnya tegangan yang ditimbulkan oleh sumber-sumber tegangan pokok, yaitu (1) proses pertumbuhan fisiologis, (2) frustasifrustasi, (3) konflik-konflik, dan (4) ancaman-ancaman. Untuk mengatasi sumber tegangan 
pokok di atas, seorang individu melakukan dua cara, yaitu identifikasi dan pemindahan (Hall, Calvin S \& G Lindzey, 2005).

Identifikasi merupakan cara dimana seseorang dapat memperoleh kembali suatu objek yang telah hilang dengan cara mengambil ciri-ciri orang lain dan menjadikan bagian yang tak terpisahkan dari kepribadiannya sendiri. Orang tidak perlu mengidentifikasikan diri dengan orang lain pada semua aspeknya. Biasanya orang memilih dan hanya mengambil hal-hal yang dirasakannya akan menolong untuk mencapai tujuan yang diinginkan. Hal terpenting adalah, apakah identifikasi itu membantu mereduksikan tegangan; jika ya maka kualitas itu diambil alih, kalau tidak maka akan dibuang. Orang dapat mengidentifikasikan diri dengan binatang-binatang, tokoh khayalan, lembaga-lembaga, gagasan-gagasan abstrak, benda-benda mati maupun manusia-manusia lain.

Pemindahan (displacement) adalah pemindahan perasaan yang tidak menyenangkan atau suatu objek yang tidak dapat memberikan kepuasan karena adanya rintangan dari dalam atau luar, maka ia akan mencari objek lain untuk mereduksikan tegangannya (Hall, Calvin S \& G Lindzey, 2005). Apabila objek pilihan sesuatu insting yang asli tidak dapat dicapai karena rintangan, baik rintangan dari dalam maupun dari luar, maka terbentuklah kateksis yang baru, kecuali kalau terjadi penekanan yang cukup kuat. Apabila kateksis yang baru ini tidak dapat dipenuhi, akan terjadi kateksis yang lain pula. Demikian seterusnya sampai ada objek yang dapat dipakai untuk mereduksikan tegangan; objek ini akan dipakai terus sampai saat habis kemampuannya untuk mereduksikan tegangan. Selama proses pemindahan itu sumber dan tujuan insting tetap, hanya objeknya yang berubah-ubah. Dalam hal itu jarang sekali objek pengganti itu dapat memberi pemuasan sebesar objek aslinya. Sebagai akibat dari bermacammacam pemindahan objek itu, maka terjadilah penumpukan tegangan yang kemudian bertindak sebagai kekuatan pendorong yang tetap bagi tingkah laku(Feist \& J. Feist., 2010) .

\subsubsection{Mekanisme Pertahanan Diri}

Dibawah tekanan kecemasan yang berlebih-lebihan, ego kadang-kadang terpaksa menempuh cara-cara ekstrim untuk menghilangkan tekanan. Cara-cara itu disebut mekanisme pertahanan. Mekanisme-pertahanan yang pokok adalah represi, fiksasi, dan pembentukan reaksi. 
Represi (repression) adalah mekanisme pertahanan yang paling dasar, karena muncul juga pada bentuk-bentuk mekanisme pertahanan lain. Apabila ego terancam oleh dorongandorongan id yang tidak dikehendaki, ego melindungi diri dengan merepresi dorongan tersebut dengan cara memaksa masuk ke alam tidak sadar. Dorongan tersebut di alam tidak sadar tidak berubah. Dorongan ini bisa mendesak masuk ke alam sadar dalam bentuk yang tidak berubah yang menimbulkan kecemasan. Namun dapat juga diekspresikan dalam bentuk-bentuk lain atau terselubung. Dorongan yang mengalami tekanan tersebut juga bisa tersalurkan lewat mimpi, salah ucap, ataupun bentuk-bentuk mekanisme pertahanan lainnya (Feist \& J. Feist., 2010).

Fiksasi (fixation), menurut Freud seperti dikutip oleh Hall dan Feist (Hall, Calvin S \& G Lindzey, 2005), (Feist \& J. Feist., 2010), pada perkembangan normal, kepribadian akan melewati serangkaian tahap untuk mencapai kematangan. Akan tetapi, setiap langkah baru yang ditempuh mengandung frustasi dan kecemasan, apabila perkembangan lebih lanjut memunculkan kecemasan yang terlalu besar maka ego mengambil strategi untuk bertahan pada tahap tersebut yang dianggap lebih nyaman. Pertahanan seperti ini disebut fiksasi. Sebagai contoh, orang-orang yang terus menerus mendapatkan kepuasan lewat makan, minum, merokok atau bicara bisa jadi akan memiliki fiksasi oral.

Pembentukan Reaksi (reaction formation) adalah salah satu cara agar dorongan yang ditekan tersebut bisa disadari dengan cara menyembunyikan diri dalam selubung yang berbeda dengan bentuk semula. Perilaku ini dapat dikenali dari sifatnya yang berlebih-lebihan dan bentuk yang obsesif juga kompulsif (Feist \& J. Feist., 2010).

\subsubsection{Mimpi}

Salah satu cara pemindahan adalah mimpi. Jika dorongan atau ketegangan tidak tersalurkan dalam kehidupan nyata, maka terjadi pemindahan dalam keadaan tidur melalui mimpi. Menurut Freud hampir semua mimpi merupakan upaya pemenuhan keinginan. Sejumlah keinginan tampak jelas dan diungkapkan melalui muatan manifes. Akan tetapi kebanyakan upaya pemenuhan keinginan diungkapkan melalui muatan laten dan hanya tafsir mimpilah yang bisa mengungkapkan keinginan tersebut. Freud meyakini bahwa mimpi dibentuk di alam tidak sadar, mencoba masuk ke alam sadar. Selanjutnya Freud (2002) mengatakan 
bahwa kelainan mental dimulai dari mimpi atau khayalan yang terwujud dalam bentuk mimpi, karena suasana hati yang terbangun dari mimpi terbawa terus seharian.

Macam-macam mimpi. Mimpi muncul karena adanya harapan dan isi mimpi adalah ekspresi dari harapan atau terpenuhinya harapan dalam bentuk halusinasi. Menurut Freud (Freud, 2002:86-102)mimpi terjadi lewat 3 jalan: Pertama, mimpi sebagai stimulus pengganggu tidur adalah bentuk reaksi pikiran untuk menstimulasi tindakan selama tidur. Kedua mimpi melalui lamunan (day-dream) yang merupakan keinginan dari diri manusia untuk memenuhi ambisi atau hasrat yang belum tercapai. Lamunan adalah hasil fantasi. Kita tidak melihat tapi hanya membayangkan. Lamunan berisi peristiwa yang memberi kepuasan terhadap ambisi egoistik, kekuasaan atau hasrat erotik. Ketiga mimpi hipnotis, yakni jenis mimpi yang disebut sebagai kondisi tidur buatan. Mimpi hipnotis tidak ada hubungannya dengan dunia luar tapi mimpi hipnotis dapat dikendalikan oleh orang yang menghipnotis (Freud, 2002).

Selanjutnya Freud (2002) menyebutkan mimpi ada yang datang sekali, namun ada juga yang mendapat mimpi terus menerus dengan isi yang sama. Mimpi yang dialami individu secara terus-menerus, dapat menyebabkan seseorang mengalami kelainan kejiwaan, seperti cemas, takut, dan gelisah yang bisa memaksa individu untuk berbuat sesuatu.

Cara kerja mimpi, menurut Freud seperti yang dikutip Feist (Feist \& J. Feist., 2010) mimpi terdiri atas muatan manifes dan muatan laten. Muatan manifes dari mimpi adalah makna mimpi pada permukaan atau deskripsi sadar yang disampaikan oleh orang yang bermimpi, sedangkan muatan laten hal-hal yang tidak disadari. Transformasi mimpi laten menjadi mimpi manifes melalui tiga proses, yaitu: Pertama Kondensasi yang mengacu pada kenyataan bahwa muatan manifes mimpi tidak seluas muatan pada tingkat laten, materi tidak sadar diringkas atau dikondensasikan sebelum muncul di tingkat manifes. Kedua pemindahan yang berarti gambaran mimpi digantikan oleh gagasan lain yang tidak ada kaitannya. Ketiga Simbolisasi, yaitu kondensasi dan pengalihan muatan ini berlangsung mengunakan simbol. Gambaran gambaran tertentu direpresentasikan secara universal oleh figur-figur yang tampaknya tak berbahaya.

Distorsi mimpi, menurut Freud, mimpi mengalami distorsi yang menyebabkan mimpi tampak aneh dan tidak jelas. Distorsi disebabkan adanya sensor mimpi berupa modifikasi, 
penjamaran atau ungkapan tersembunyi dari maksud sebenarnya. Keinginan-keinginan yang tersensor yang diekspresikan dalam bentuk terdistorsi dalam mimpi merupakan manifestasi egoisme yang kejam dan tak terbatasi, karena ego orang yang bermimpi itu selalu muncul dalam setiap mimpi dan memainkan peran utama, meskipun ego tersebut menyamarkan diri dalam isi manifes mimpi. Selanjutnya Freud meyakini bahwa mimpi seperti ini berhubungan dengan arah pemikiran selama tidur, yaitu keinginan menarik diri dari dunia luar (Freud, 2002).

\subsection{Metode Penelitian}

Metode yang digunakan adalah metode deskriptis analisis yaitu mendeskripsikan faktafakta yang disusul dengan analisis. Analisis tersebut tidak semata-mata menguraikan melainkan juga memberikan pemahaman dan penjelasan secukupnya (Kutha Ratna, 2004). Untuk itu dalam penelitian ini dilakukan analisis dengan dua cara. Pertama menganalisis unsur unsur yang terkandung dalam karya sastra melalui pendekatan struktural, yakni suatu cara pendekatan karya sastra yang menggunakan ilmu bahasa sebagai dasarnya dan bertujuan untuk membongkar dan memaparkan secermat, seteliti mungkin keterkaitan dan keterjalinan semua anasir dan aspek karya sastra yng bersama sama menghasilkan makna menyeluruh. ((Teeuw, 1984:135). Kedua melalui ancangan psikologis sastra yang berhubungan dengan karya sastra. Karya sastra dianggap sebagai hasil aktivitas penulis yang dikaitkan dengan gejala-gejala kejiwaan seperti obsesi, kontemplasi, konpensasi, sublimasi dan sebagainya.

\section{Hasil dan Pembahasan}

Penelitian ini menganalisis makna mimpi, dan kaitannya dengan kematian dan kecemasan yang terjadi pada tokoh-tokoh wanita yang terdapat pada cerpen Shirakawa Yo Fune yaitu Terako dan Shiori. Terako digambarkan sebagai seorang wanita muda yang tidak mempunyai pekerjaan, kehidupannya sehari-hari dilewatkan dengan bersantai, berbelanja dan mencuci bajunya sendiri. Pada awalnya dia bekerja pada sebuah perusahaan kecil yang sangat sibuk, tetapi sejak dia menjalin hubungan dengan pria beristri bernama Iwanaga dia memutuskan untuk berhenti, alasannya karena tidak cukup waktu untuk bertemu Iwanaga. Untuk menopang hidupnya setiap bulan Iwanaga memberikan uang yang cukup banyak. 
Hubungannya dengan Iwanaga tidak memuaskan Id yang bekerja berdasarkan prinsip kesenangan. Iwanaga tidak bisa benar-benar dimilikinya walaupun mereka saling mencintai, dia masih terikat perkawinan dengan istrinya yang sekarang sedang terbaring koma karena kecelakaan. Egonya yang bekerja berdasarkan insting menuntut untuk memiliki Iwanaga sepenuhnya, selalu berada di sampingnya dan hidup bersamanya, namun superego yang bekerja berdasarkan prinsip moral dan norma-norma sosial menghalanginya untuk meminta Iwanaga menceraikan istrinya yang sedang koma. Ego yang bekerja berdasarkan prinsip realitas tidak dapat memuaskan id sehingga menimbulkan kecemasan.

Kecemasan Terako yang tidak bisa memiliki Iwananga sepenuhnya dan ketakutan akan kehilangan Iwanaga adalah kecemasan realitas yang timbul akibat rasio yang tidak mengizinkan keinginan dalam id dipuaskan. Fungsi kecemasan adalah memperingatkan adanya bahaya dan memotivasi individu untuk melakukan sesuatu berupa mekanisme pertahanan yaitu pemindahan. Pemindahan dari Terako adalah dengan tidur pulas. Tidur adalah suatu kondisi saat kita menolak berhubungan dengan dunia luar dan menangkal stimulasi dari sana. Semenjak kecil, Terako yang merupakan anak tunggal sering ditinggal sendirian sampai malam di rumah, dan untuk mengatasi ketakutan karena kesendiriannya dia akan tidur dengan segera. Hal tersebut juga merupakan pemindahan.

Entah sejak kapan, ketika saya sedang sendirian, saya tidur lelap. Tidur yang terus menerus seperti gelombang. Yah bagaimana lagi. Tidur yang sangat lelap, suara telpon, suara mobil dari luar hanya melewati telinga saya. Tidak merasakan luka sedikitpun, tidak merasakan kesepian. Di sana hanya ada dunia yang tidur. Ketika saya terbangun saya akan merasakan kesepian. Ketika saya melhat langit yang mendung, baru saya menyadari waktu sudah banyak berlalu semenjak saya tidur (Banana, 1989, p.9).

Kecemasan realitas berkembang menjadi tidak proposional pada situasi tertentu dan menimbulkan kecemasan neorosis sekaligus realistis. Situasi ini dikarenakan ada bahaya yang dirasakan individu berasal dari luar yang tidak diketahuinya. Kecemasan ini semakin memotivasi Terako untuk tidur pada setiap dia merasa kesepian dan tidak berada di samping Iwanaga. Id nya akan terpuaskan apabila dia bersama Iwanaga seperti kutipan berikut.

Mari kita menginap. Baiklah kataku sembari menggenggam tangannya dengan bahagia, dia tersenyum. Aku sangat senang. Malam yang aku sukai. Sangat kusukai. Sepanjang malam apapun mungkin dilakukan. Aku sedikitpun tidak mengantuk (Banana, 1989, p.14). 
Shiori adalah satu satunya teman dekat Terako, mereka pernah tinggal satu apartemen, kepada Shiori dia bisa menceritakan keluh kesahnya, menceritakan rumitnya hubungannya dengan Iwanaga dan keresahannya tentang ketidak pastian hubungannya dengan Iwanaga, Bersama Shiori hidupnya terasa menyenangkan. Berikut gambaran Terako tentang Shiori

Saat saya bersama Shiori saya merasakan saya lebih menyukai wanita daripada pria. Perasaan bersama Shiori bukan perasaan seperti lesbian. Dapat dikatakan dia ibu yang baik dan tinggal bersamanya menyenangkan. Dia baik dan sedikit gemuk, matanya sangat sipit, dadanya besar. Kamu tidak bisa mengatakannya cantik dan dia sangat penyabar, sehingga kamu berfikir dia seorang ibu. Dan dia adalah seorang wanita yang tidak memiliki daya tarik seks (Banana, 1989, p.22).

Karena tuntutan pekerjaan, Shiori pindah ke apartemennya sendiri, yang juga merupakan tempat dia bekerja. Shiori mempunyai pekerjaan yang aneh yaitu menemani pria kesepian tidur di malam hari. Dia hanya menemani tidur tanpa melakukan aktivitas seks dan membuatkan kopi kalau pria yang ditemaninya itu meminta. Tetapi karena sesuatu alasan yang tidak dimengerti oleh Terako, Shiori bunuh diri dengan cara menelan pil tidur melebihi dosis. Terako sangat shock, dia tidak mengetahui apa alasan Shiori bunuh diri. Dia tidak bisa menerima bahwa Shiori telah meninggal, bahkan dia tidak bisa membicarakan kepada Iwanaga.

Menurut teori yang dikembangkan oleh Freud, id pada Terako yang merupakan bagian inti dari kepribadian yang bekerja berdasarkan prinsip kesenangan, tidak mampu mereduksi peningkatan energi karena ketegangan yang disebabkan kehilangan Shiori sehingga terjadi perpindahan energi pada ego, apabila ego mampu menangulangi maka tidak terjadi kecemasan, namun ternyata ego pada Terako tidak mampu menanggulangi maka agar tidak terjadi ketegangan dilakukan mekanisme pertahanan dengan cara merepresi kematian Shiori tersebut ke alam bawah sadar. Namun sesuatu yang direpresi dapat muncul ke alam sadar berupa mimpi, seperti kutipan berikut,

Saya bisa melihatnya dengan jelas segala sesuatu dalam mimpi itu benar benar nyata. Aku terbangun di kamarku. Pada malam itu, di meja kayu bulat yang ada di ruangan dapur dan juga ruang makan yang berada di depan kamarku aku melihat Shiori sedang menyusun bunga dia memakai jaket pink dan celana khaki yang biasa dia kenakan dan memakai sandal yang selalu dipakainya (Banana, 1989, p.54).

Mimpi yang dialami Terako sangat panjang. Freud membedakan mimpi berdasarkan panjangnya. Ada yang pendek, berisi satu gambaran atau satu pemikiran ada mimpi yang 
memiliki isi yang lengkap dan berlangsung sangat lama, adakalanya mimpi mengambarkan peristiwa yang jelas seperti kehidupan nyata, sehingga saat bangun individu tidak segera menyadari bahwa itu mimpi (2002, p.88). Hal ini terjadi pada Terako. Dorongan atau ketegangan tidak tersalurkan dalam kehidupan nyata, maka terjadi pengalihan dalam keadaan tidur melalui mimpi. Menurut Freud semua mimpi merupakan upaya pemenuhan keinginan. Terako merasa terpuaskan bertemu Shiori dalam mimpi, kecemasannya tereduksi dengan baik sehingga dia merasa senang dan gembira.

Pada awalnya suara telpon yang berasal dari Iwanaga bisa membangunkannya dari tidur sendirian. Tetapi kematian Shiori menyebabkan dia tidak punya teman bicara selain Iwanaga, id tidak terpuaskan karena Iwanaga tidak berinisiatif untuk meninggalkan istrinya. Ego tidak berhasil mereduksi kecemasan yang memicu represi untuk mengurangi kecemasan dengan tidur lelap yang sangat lama, terutama ketika dia sendirian atau Iwanaga tidak di sampingnya. Bahkan akhirnya suara telpon dari Iwananga yang biasa membangunkannya tidak mampu membangunkannya, seperti pada kutipan berikut,

Aku melepaskan blus dan rok, membuang ke lantai dan naik ke tempat tidur, selimut terasa sejuk dan bantal menjadikanku sangat mengantuk. Aku baru saja mendengkur ketika menyadari telpon berdering. Itu pasti telepon dari iwanaga. Telepon terus berdering seperti pernyataan cintanya. Tetapi bagaimanapun saya mencoba saya tidak bisa membuka mata. saya pikir ini benar-benar seperti kutukan. Pikiran saya benar benar sadar tetapi bagaimanapun saya tidak bisa bangun (Banana, 1989).

Kecemasan yang tidak dapat direduksinya menyebabkan Terako bisa tidur dalam waktu yang panjang melewati siang dan malam. Hal ini adalah suatu cara untuk mereduksi ketegangan. Menurut Freud ((2002) tidur adalah kondisi saat individu menolak berhubungan dengan dunia luar dan menarik diri darinya, dengan tidur individu berusaha untuk mendapatkan kembali kondisi yang penuh kehangatan dan tidak ada stimulus.

Walaupun begitu tidur lama tidak dapat mereduksi kecemasan yang disebabkan ketegangan ketika dia bangun. Ketegangan terjadi karena id pada Terako sangat ingin mengetahui seperti apa istri Iwanaga, apa alasan Iwanaga sehingga tidak tega untuk meninggalkannya. Id yang bekerja berdasarkan prinsip kesenangan sepenuhnya berada pada alam tidak sadar; yang merupakan tempat segala dorongan dan insting beserta hasrat-hasrat yang umumnya tidak disadari. Dorongan yang ada pada alam bawah sadar itu akhirnya 
menembus masuk ke alam sadar berupa lamunan bertemu istri iwanaga. Lamunan (daydream) menurut Freud ((Freud, 2002) merupakan keinginan dari manusia untuk memenuhi ambisi atau hasrat yang belum tercapai. Lamunan dapat terbawa dalam pikiran dan diimajinasikan dengan jelas. Lamunan yang terjadi pada Terako adalah peristiwa pertemuannya dengan seorang wanita yang tidak pernah dikenalnya, berikut kutipannya,

"Apakah kamu merasa tidak enak badan? ".suara seorang wanita terdengar ditelingaku, untuk sesaat aku ingin seolah-olah sakit tapi aku malu, nanti dia akan salah paham, saya menyerah dan mengangkat kepalaku. Wanita itu ada disebelahku seperti anak SMA dan memakai jeans. Matanya seperti kristal menatap kepadaku, mata yang besar dan misterius. "tidak apa-apa,hanya sedikit mengantuk"."wajah anda pucat", katanya prihatin."tidak apa-apa, terimakasih". Aku tersenyum, dan dia pun tersenyum.Tanaman hijau bergetar lembut tertiup angin dan beraroma dingin. Wanita itu duduk diam disampingku, akupun tidak bisa berdiri, sehingga duduk dan menatap lurus kedepan. Pada wanita itu ada sesuatu yang aneh, seperti dia tidak ada di sekitarku. Rambutnya panjang menjuntai di atas bahu, seorang wanita yang cantik namun saya merasakan sesuatu tentang dia. Saya mngira mungkin ada yang aneh dengan kepalanya. Aku mulai merasa nyaman karena bersama seseorang. (Banana, 1989, p.66)

Peristiwa yang terjadi pada lamunan itu sangat panjang. Wanita yang ada pada lamunan itu menyarankannya segera mencari pekerjaan. Sebaiknya pekerjaan sambilan atau penjaga pameran atau semacam itu asal jangan pekerjaan kantoran. Karena tidak cocok dengannya yang suka tertidur. Lamunan itu sebenarnya adalah dorongan atau hasrat dari insting hidup yang bertujuan untuk mempertahankan hidup individu. Id yang merupakan sumber insting hidup pada Terako merasakan tidur lelap tidak menyenangkan bahkan mulai merusak hidupnya, namun tidak disadarinya. Keadaan yang tidak menyenangkan ini muncul ke alam sadar berupa lamunan.

Kemunculan wanita pada lamunan disebabkan hasrat untuk mengenal istri Iwanaga. Melalui percakapan-percakapan yang selintas, Iwanaga mengatakan bahwa istrinya wanita yang baik, berpendidikan mempunyai rambut keriting yang bagus dan hal-hal yang sepele bisa membuatnya menangis. Gambaran istri Iwanaga itu direpresi ke alam bawah sadar dan kemudian muncul berupa wanita muda. Pada tahap ini terjadi proses kondensasi muatan laten mimpi sebelum menjadi muatan manifes melalui simbolisasi dan pemindahan. Gambarangambaran istri Iwanaga direpresentasikan oleh seorang wanita muda berambut lurus panjang sebuah figur yang tampaknya tidak berbahaya dan berbeda. Pada proses ini pemindahan yang 
terjadi adalah kekhawatiran bahwa wanita tersebut akan menyalahkannya karena perselingkuhannya dengan Iwanaga, beralih menjadi bersimpati, dan memberikan nasihat serta cara agar dia bisa hidup normal, seperti terlihat pada kutipan berikut,

Setelah kamu di sana, pergi ke kios suratkabar dan ambil Jurnal Job-Hunter. Kemudian cari pekerjaan untukmu. Walaupun untuk waktu yang singkat, Ambil. Kamu bisa menjadi seorang model atau peraga pada sebuah pameran. Pekerjaan kantoran tidak cocok untukmu karena kamu pengantuk. Kamu butuh pekerjaan yang membuat kamu berdiri, mengerakkan tangan dan kaki. Lakukanlah. Ok. Saya tidak bisa melihat kamu terus begini. Jika kamu terus seperti ini, kamu akan terus terjebak, dan kamu tidak akan bisa kembali seperti kamu yang dahulu (Banana, 1989, p.67).

\section{Simpulan}

Cerita pendek Shirakawa Yo Fune menceritakan tokoh Terako dan Shiori. Terako seorang wanita yang tidak mempunyai pekerjaan dan menjalin hubungan dengan Iwanaga seorang pria beristri. Hubungan dengan Iwanaga tidak berjalan lancar karena Iwanaga tidak sepenuhnya menjadi miliknya apalagi Iwanaga tidak dapat melepaskan diri dari istrinya walaupun istrinya sedang dalam keadaan koma. Keadaan ini mempengaruhi kehidupan Terako. Sedangkan Shiori adalah satu-satunya teman dekat yang selalu menjadi tempat curahan hati Terako. Shiori mempunyai pekerjaan yang aneh yaitu menjadi teman tidur pria kesepian. Karena sesuatu hal yang tidak diketahui Shiori bunuh diri. Terako kehilangan teman tempat dia mengadu dan mencurahkan segala keluh kesah hidupnya.

Melalui analisis pada tokoh, terlihat tokoh Terako mengalami kecemasan realitas karena dia tidak dapat memiliki Iwanaga sepenuhnya. Kecemasan tidak dapat direduksinya sehingga terjadi pemindahan berupa tidur dan kemudian berkembang menjadi kecemasan neorosis dengan selalu tidur yang sangat lelap terutama pada saat dia sendirian . Terako juga merepresi kematian Shiori ke alam bawah sadar tetapi kemudian muncul ke alam sadar berupa mimpi. Ketegangan juga terjadi karena hasrat Terako yang tidak terpenuhi yaitu hasrat untuk mengetahui keadaan istri Iwanaga dan apa penyebab Iwanaga tidak mampu meninggalkan istrnya yang sedang koma walaupun dia sangat mencintai Terako. Hasrat itu muncul ke alam sadar berupa lamunan bertemu istri Iwanaga. Pada lamunan ini terjadi proses kondensasi muatan laten mimpi sebelum menjadi muatan manifes melalui pemindahan dan simbolisasi. 
Pada cerita pendek ini terlihat adanya hubungan antara kematian dan kecemasan. Kecemasan terjadi karena ketegangan yang tidak dapat tereduksi dengan baik yang semuannya dipicu oleh kematian orang terdekat. Ketegangan yang tidak tereduksi akan menimbulkan kecemasan. Untuk mengatasi ketegangan-ketegangan, tokoh-tokoh tersebut melakukan identifikasi dan pemindahan. Kecemasan juga memotivasi tokoh untuk melakukan mekanisme pertahanan berupa represi yang kemudian memicu munculnya mimpi dan lamunan, serta fiksasi.

\section{Daftar Pustaka}

Banana, Y. (1989). Shirakawa Yo Fune. Japan: Shinchosha.

Endraswara, S. (2008). Metode Penelitian Psikologi Sastra: Teori Langkah dan Penerapan. Yogyakarta: FBS Universitas Negeri.

Feist, J., \& J. Feist., G. (2010). Teori Kepribadian. Jakarta: Salemba Humanika.

Freud, S. (2002). Psikoanalisis Sigmund Freud. Yogyakarta: Ikon.

Hall, Calvin S \& G Lindzey, G. (2005). Teori-teori Psikodinamik (Klinis). Yogyakarta: Kanisius.

Kutha Ratna, N. (2004). Teori Metode, dan Teknik Penelitian Sastra. Yogyakarta: Pustaka Pelajar. Teeuw, A. (1984). Sastra dan Ilmu Sastra. Pengantar Teori Sastra. Jakarta: Jakarta: PT Dunia Pustaka Jaya. 